\title{
Influence of Penstock Outlet, Number of V-Blades, Flat Blade Lateral Twist Angle and Hub to Blade Ratio on the Performance of a Simplified Pico Hydropower System
}

\author{
By Alex Okibe Edeoja* , Matthew Ekoja ${ }^{\dagger}$ \& Taofeek A. Yusuft
}

A study to determine the influence of penstock outlet, number of v-blades, flat blade lateral twist angle and the hub to blade ratio on the performance of the Pico-hydro system has been conducted. Five turbine runners with 8, 9, 10, 11 and 12 v-blades were fabricated and tested on an already existing system. A runner with adjustable flat blades was also fabricated and tested for twist angles of $50^{\circ}, 55^{\circ}, 60^{\circ}, 75^{\circ}$ and $90^{\circ}$. Runners with v-blades but having hub to blade ratios of 0.3, 0.4, 0.55, 0.65 and 0.7 were also tested. The turbine was connected to $3.9 \mathrm{kVA}$ alternator via a v-belt drive and a 1 Hp pump was used to sustain the flow. The turbine and alternator shaft speeds were measured, and the level of water in the overhead and underground reservoirs monitored. The flow rate, available head and the hydraulic power were computed for each operation. The results obtained indicated that using a combination of a runner with 12 blades and a penstock outlet of $20 \mathrm{~mm}, 0.55 \mathrm{hub}$ to blade ratio and lateral twist angles greater than $75^{\circ}$ combined with penstock outlets larger than $20 \mathrm{~mm}$ have the potentials of better performance in terms of power generation. The results of correlation and reliability test using Cronbach's alpha carried out on the data at 95\% confirmed these findings. This will be very useful for further development of the system in order to attain implementable status as a clean and decentralized energy source.

Keywords: Blade Lateral Twist Angle, Hub to Blade Ratio, Number of Blades, Pico Hydro, Penstock Outlet.

\section{Introduction}

The challenge of the $21^{\text {st }}$ century is how to develop sustainably and maintain the quality of life for a growing population with higher expectations for wellbeing. Underlying this challenge is the need for sufficient and sustainable supplies of energy to provide the economic activity underpinning these expectations. The measure of development in any society is synonymous with the level of energy consumption (British Petroleum 2017, Newell and Phillips 2016, SEP 2013, ECA 2014, Edeoja et al. 2015a). Energy plays the most vital role in the economic growth, progress, and development, as well as poverty eradication and security of any nation. Uninterrupted energy supply is a vital issue for all countries today (Obande et al. 2017, Arto et al. 2016, Lajqi et al. 2016, MDGs 2015, UNDESA 2014). Future economic growth crucially depends on the long term availability of

\footnotetext{
*Senior Lecturer, Federal University of Agriculture, Makurdi, Nigeria.

${ }^{\dagger}$ Lecturer I, Federal University of Agriculture, Makurdi, Nigeria.

${ }^{*}$ Lecturer II, Federal University of Agriculture, Makurdi, Nigeria.
} 
energy from sources that are sustainable, affordable, accessible, and environmentally friendly. It is noted that the standard of living of a given country can be directly related to the per capita energy consumption, as the per capita energy consumption is a measure of the per capita income as well as a measure of the prosperity of a nation (Lipu et al. 2017, Shittu 2015, WHO 2015, Portale and de Wit 2014, Bergasse et al. 2013, Saatci and Dumrul 2013, Pirlogea and Cicea 2012, Lior 2010).

World Energy Council (2013) addressed the main factors that have influenced the development of the global energy sector the most over the previous two decades adding that the world has changed significantly in this period. The council summarized the principal drivers that have shaped energy supply and use to include sharp increase in the price of oil since 2001, financial crisis and slow economic growth with drastic reduction in energy consumption in large economies, shale gas in North America, the Fukushima Daiichi nuclear accident and the volatile political situation in the energy supplying countries in the Middle East and North Africa. Others are lack of global agreement on climate change mitigation, collapse of $\mathrm{CO}_{2}$ prices in the European Emissions Trading System, exponential growth in renewables, deployment of 'smart' technologies, energy efficiency potential still remaining untapped, and growing public concern about new infrastructure projects, including energy projects (Samy 2017, Hossain et al. 2017, Choi et al. 2017).

Currently, the global energy demand is rising fast as population and emerging economies like China and India are growing exponentially with small and medium enterprises springing up. In developing countries of Africa like Nigeria, the International Energy Agency forecasts that energy demand would be 50\% higher in 2030 than they are today (British Petroleum 2017, British Petroleum 2016, UNIDO, 2010, Sambo 2008a, Sambo 2008b, IEA 2007). Yet fossil fuels on which the world mostly depends are finite and are not environmentally friendly (Akuru and Okoro 2011, Williams and Alhaji 2003). There is therefore a gradually shifting of attention to potential renewable energy resources for power generation like wind, solar and hydro power resources. Renewable energy constitutes about $15 \%$ of the world's energy mix with hydropower making most of it (REN21 2016, UNFCCC 2015, REN21 2014, Bala 2013a, Bala 2013b, UNIDO 2009).

Access to electricity is a prime key to development as it provides light, heat and power for productive uses and communication, and the global demand keeps growing. A vast majority of the people in developing countries, especially in rural areas, do not have access to electricity (IEA 2015, Shezi 2015, Yuksel et al. 2013, Sambo 2005). This number keeps increasing despite the rural electrification programs because they are not sufficient to cope with the population growth or the political will in some of the places is not strong enough or absent (Omprasad 2016, Ramos et al. 2012, Adejumobi et al. 2013, Wang 2009). Moreover, despite the fact that about $80 \%$ of the world's population lives in developing countries, they consume only about $20 \%$ of the global commercial energy. According to the World Bank, most of the world's poor people spend more than $12 \%$ of their total income on energy, which is much more than what a middle-income family in the developed world spends (World Bank 2008, World Bank 2006). 
Studies have indicated that about $40 \%$ Nigerian households have access to the national grid with more than $45 \%$ not having access to any form of electricity. About $6 \%$ have supported their access to the grid with standby generators and more than $3 \%$ completely relied on them. Also, about $1.1 \%$ of households have access to the rural electrification programs while a vast majority of Nigerians still use firewood for cooking with about $20 \%$ relying on kerosene. This is a direct consequence of low access to and low reliability of electricity services. These findings show the urgent need for efforts for further developments of the overall Nigerian electricity sector as well as rural electrification programs to ensure rapid economic development (Edomah 2016, Adejumobi et al. 2013, Oseni et al. 2012, Sambo 2008c). There is a need to revolutionize the way energy is produced and used to reduce these impacts while providing energy services to the billions of people who have inadequate or no access to electricity (Shezi 2015, Mustonen et al. 2010). Population growth makes the challenge even harder. The energy revolution will require moving from electricity systems based on large-scale fossil fuels, large hydro and nuclear fission plants to the ones based on new renewable sources and massive improvements in the efficiency of production, transportation, and storage and use of energy (Kumar and Biswas 2017, Okonkwo et al. 2017, Paun and Paun 2017, Ribal et al. 2017, Nguyen et al. 2016).

Water is the better choice among renewable sources because a small-scale hydropower is a relatively very cost-effective and reliable energy technology to be considered for providing clean electricity generation (Liu et al. 2013a, Liu et al. 2013b). Hydropower is a renewable, economical, non-polluting and environmentally benign. It accounts for about $19 \%$ of global electricity production from both large and small power plant second only to fossil fuels (Adamkowski 2012, Gatte and Kadhim 2012, Mishra et al. 2011a, Mishra et al. 2011b). The world has endless potential for hydropower generation. A lot of hydropower stations have been built all over the world and many more projects with a capacity above 100, 000 MW currently going on globally. Asia has the largest contribution of around 84, 000 MW (Nikolaisen 2015, Kaunda et al. 2012). In Nigeria, the potential is about 14,750 MW of power. About 1980 MW of this potential has been explored at Kainji, Jebba and Shiroro hydropower stations, leaving 12,200 MW unexplored (Bala 2013b, Adejumobi et al. 2013, Ohunakin et al. 2011, Olusegun et al. 2010). This implies that only about $14 \%$ of the nation's hydropower potential is in use. This inability to exploit its vast hydropower potential and to the fact that the available large hydropower plants are not operating up to installed capacity has negatively impacted power supply in Nigeria (Olukanmi and Salami 2012, Akuru and Okoro 2011). The present government has resuscitated interest in developing the project at Mambilla plateau in a bid to tackle part of the power supply problem.

Hydroelectric power plants despite having many advantages over other energy sources, have potentially negative environmental and socio-economic impacts (Nikolaisen 2015, Finardi and Suzzanto 2013, Hussey and Pittock 2012, Islar 2012). It is not a reliable source of energy because it depends on the hydrological cycle. Also, global climate change will increase rainfall variability and unpredictability, translating to more unpredictability, and increased flooding due to global warming is a big hazard to the safety of dams (Cunbin et al. 2012, 
Jia-kun 2012, Jager 2008). Furthermore, reservoirs lose storage capacity to sedimentation which can diminish the capacity of dams to generate power. Hydropower projects also alter the habitats of aquatic organisms and affect them directly (Baumann and Stevanella 2012, Deng et al. 2012, Deng et al. 2011, Liu et al. 2012, Fjeldstad et al. 2012, Horlacher et al. 2012). Millions of people have been relocated from their homes to make way for dams, losing their land, livelihoods and access to natural resources and enduring irreparable harm to their cultures and communities (Melikoglu 2013, Bohlen and Lewis 2009). There is also growing evidence suggesting that reservoirs emit significant quantities of greenhouse gases especially in the lowland tropics (Chanudet et al. 2012, Cheng et al. 2012, Amor et al. 2011, Liu et al. 2011, Miller et al. 2011). Also, hydropower is often falsely promoted as cheap and reliable, projects are prone to cost overruns and often do not produce as much power as predicted (Aslani 2013, Goodland 2010, Sternberg 2010). The foregoing demerits are more directly applicable to large hydropower schemes which inform the need to resort to smaller schemes (mini, micro and Pico). They have continued to gain increasing popularity especially in remote areas due to design simplicity, ease of operation and relatively low environmental impacts (Wohlgemuth 2014, Pascale et al. 2011). Furthermore, communities could take advantage of simple drinking water projects or irrigation systems to install small hydro schemes.

Pico-hydro power provides a very good option for applying the advantages of hydropower while minimizing the operational and natural shortcomings. It suits the general requirements of smarter, smaller and decentralized systems, generating up to $5 \mathrm{~kW}$. It has become a very useful option in Asian developing countries where the topography inhibits the uptake of more conventional grid-connected energy systems (Nimje and Dhanjode 2015, Xuhe et al. 2014, Haidar et al. 2012, Alexander et al. 2009a, Alexander et al. 2009b, Chuenchooklin 2006, Maher et al. 2003). Over the last 30 years it has been proven as a cost effective, clean and reliable method of generating electricity and mechanical power for off-grid applications and will play an important role in rural electrification into the foreseeable future. In Nepal, as at 2013, about 300 Pico hydro schemes constructed by Practical Action are producing electricity while 900 others are used for mechanical power only (Cobb and Sharp 2013).

There are many sites suitable for Pico hydro development in Nigeria as in many other African countries. Pico hydro has made some in roads in sub Saharan Africa as well, where electrification rates are some of the world's lowest (Wang 2009). However, focus has not been given to it as part of frantic efforts to combat the energy crisis (Bala 2013b, Ajuwape and Ismail 2011). This could be most likely as a result the desire in developing countries for executing gigantic projects which most often become moribund. If fully utilized, it would contribute remarkably to reducing the energy problems of domestic and commercial consumers in addition to providing a cheap source of power to remote areas where the extension of grid system is comparatively uneconomical (Adejumobi et al. 2013, Cobb 2011, Olusegun et al. 2010).

Pico hydro systems are not prone to sabotage and terrorist attacks as individuals and communities take responsibility of safeguarding their own 
facilities. Due to the increased rate of terrorist activity in the country, the need and use for small Pico hydro is more attractive as power can be generated within the domestic environment, hence increasing energy security since generation and distribution are simplified (Othman et al. 2015, Alexander and Giddens 2008a, Alexander and Giddens 2008b, Williams 2007). While presenting significant advantages, its implementation has several challenges including a heavy dependence on site specific conditions for scheme design. Moreover, seasonal fluctuations of water levels also affect the operation of the conventional Pico hydro schemes, and low water levels do not allow optimal operation while very high ones can sweep the units away (Lahimer et al. 2012). Off the shelf systems have been designed to reduce the site specific requirement but the need for technical expertise and periodic maintenance still remains (Alexander and Giddens 2008a, Maher 2002a, Maher 2002b, Maher and Smith 2001). To further reduce the cost of the technology standard pumps and induction motors could be used in place of conventional generators and turbines (Smith and Williams 2003).

This study however focuses on the investigation of the effect of penstock outlet, turbine blade to hub ratio, the number of V-blades and the lateral twist angle of flat blades on the performance of a simplified Pico hydropower system that has been undergoing development in the Department of Mechanical Engineering, University of Agriculture, Makurdi, Nigeria, for about four years now (Edeoja and Awuniji 2017, Edeoja et al. 2017, Ipilakyaa et al. 2017, Edeoja et al. 2016a, 2016b, 2016c, 2015b). It basically involves an overhead water reservoir with a locally fabricated turbine at its foot and has an underground reservoir. A pump is used for recycling the water, PVC pressure pipes as penstocks, tapered pipes as penstock outlets and an alternator. The present development will explore all the merits of Pico hydro systems while giving control to the user and as result minimize exposure to sabotage as well as bringing the benefits of hydropower to locations without natural water sources for conventional schemes. This particular aspect will further strengthen the prospects of eventually implementing this system for the end user small energy needs.

\section{Methodology}

The fabrication of the basic components of the system was done in the Mechanical Engineering workshop of the Federal University of Agriculture, Makurdi, Nigeria. Three parameters, number of v-blades, flat blade lateral twist angle and hub to blade ratio were studied with varying penstock outlets as part of an ongoing work. The runner with v-blades comprised of a circular hub with blades welded around its periphery. The diameter of the runners as well as the hub to blade ratio was obtained from Edeoja et al. (2015b). All the hubs and blades were fabricated from a $2 \mathrm{~mm}$ and $1.5 \mathrm{~mm}$ thickness mild steel sheet respectively. Five sets of runners were fabricated with $8,9,10,11$ and 12 blades. The runner assemblies are shown in Figure 1. 
Figure 1. The Runner Assemblies with the Different Number of Blades

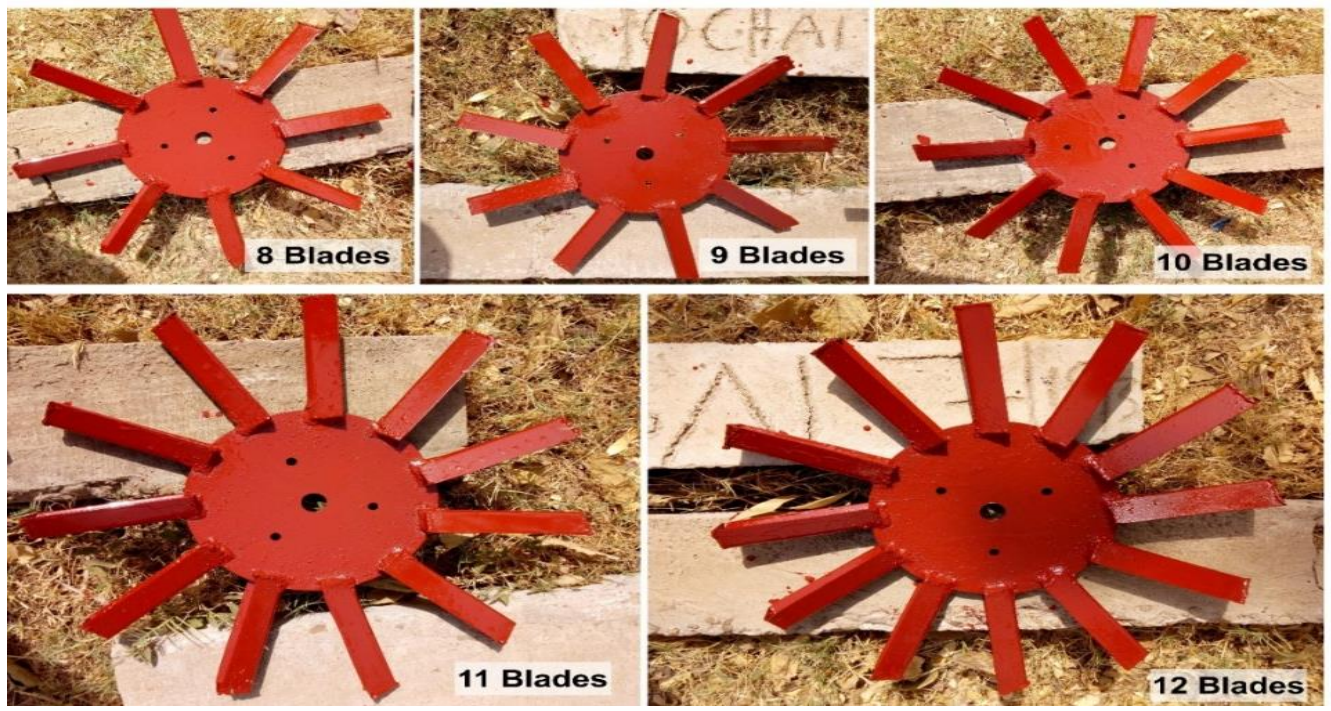

The runner with flat blades had a circular hub of diameter also taken from Edeoja et al. (2015b) with 10 blades equally spaced around its periphery. The blades were detachable from the hub to enable adjustment laterally so that the test can be carried out at different blade angles. The runner with the adjustable flat blades is shown in Figure 2.

Figure 2. The Adjustable Flat Blade Runner Assembly

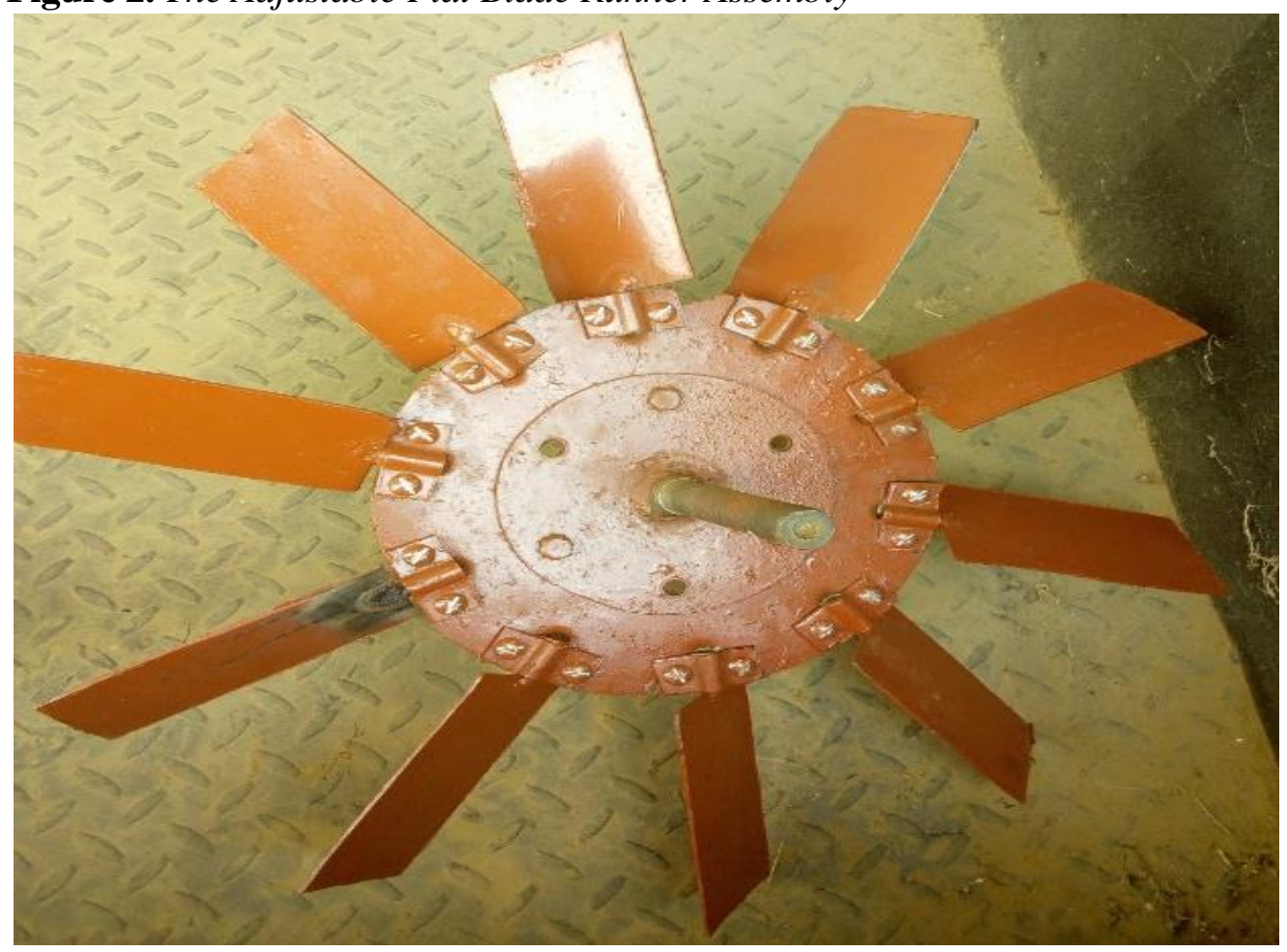


The runner with varying hub to blade ratios also had $10 \mathrm{v}$-blades based on the recommendations of Edeoja et al. (2016c). Five runners were fabricated with varying length of blades and sizes of hub attached to them. The hub to blade ratios of $0.7,0.65,055,0.4$ and 0.3 were selected around the approximate value of 0.55 reported in literature. Figure 3 shows the fabricated runners with the different hub to blade ratios.

Figure 3. The Runner Assemblies with Different Hub to Blade Ratios

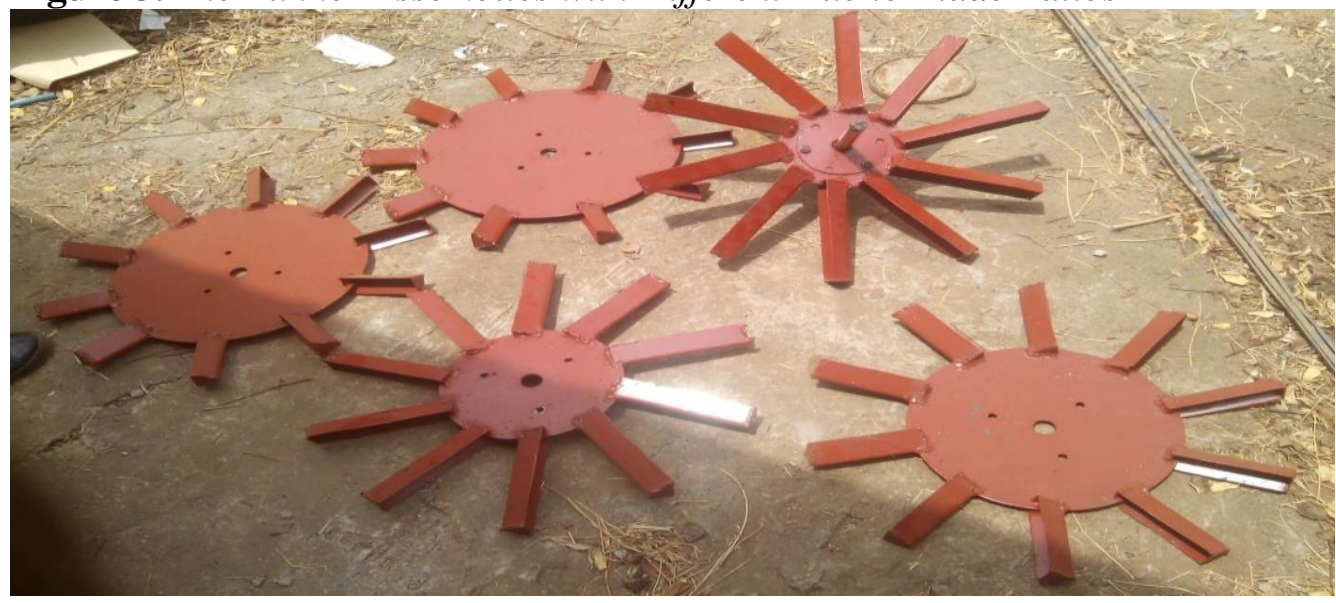

The penstock outlets used were obtained by reducing $76.2 \mathrm{~mm}$ diameter to 15 , 17.5, 20, 22.5 and $25 \mathrm{~mm}$. The choice of $76.2 \mathrm{~mm}$ and reduction to the diameters selected was based on previous aspects of this work reported by (Edeoja and Awuniji 2017, Ipilakyaa et al. 2017, Edeoja et al. 2016a). The penstock outlets used for the study are shown in Figure 4.

Figure 4. The Penstock Outlets used for the Study

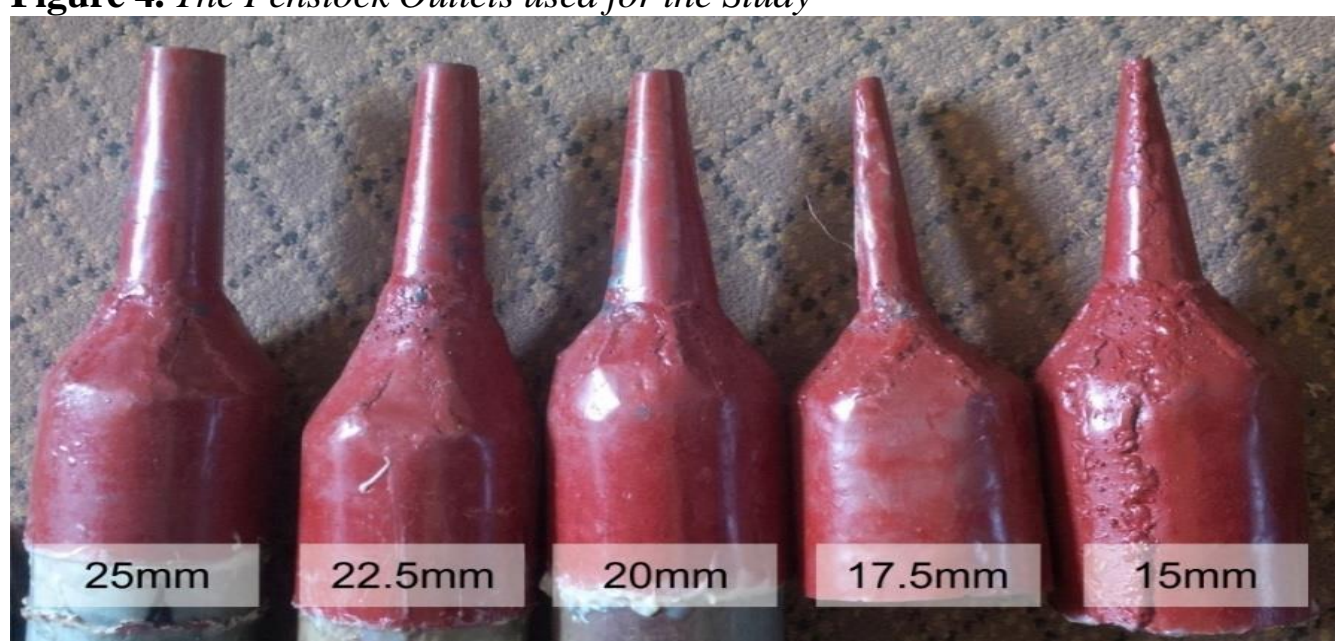

Each of the runners was clamped to the shaft flange with four M10 bolts and mounted in between two bearings and seals on the already existing turbine casing and covered to allow free spinning of the shaft and prevent leakages from the turbine one after the other. Some grease was also applied to the bearings to reduce 
friction. The turbine cover was then secured in place with M14 and M13 bolts and the turbine pulley of about $605 \mathrm{~mm}$ diameter mounted on the $20 \mathrm{~mm}$ shaft. The upper and lower ends of the $76.2 \mathrm{~mm}$ PVC penstock were then connected to the overhead tank and the outlet respectively. Care was taken to align the turbine runner, casing and the penstock outlet so as to ensure a good clearance of about 15 $\mathrm{mm}$. The turbine was then coupled to a $3.9 \mathrm{kVA}$ alternator by means of a toothed $\mathrm{v}$-belt drive onto a $50 \mathrm{~mm}$ pulley mounted on the shaft in a ratio of about 12:1.

The experimental set up for this study consists of a $1 \mathrm{Hp}, 3-10.8 \mathrm{~m}^{3} / \mathrm{h}$ pump and the locally fabricated turbine connected in a closed loop with PVC piping as penstock, a 2000 litres overhead tank and a 3000 litres underground reservoir. Figure 5 shows a picture of the entire system.

Figure 5. The Experimental Set up of the System

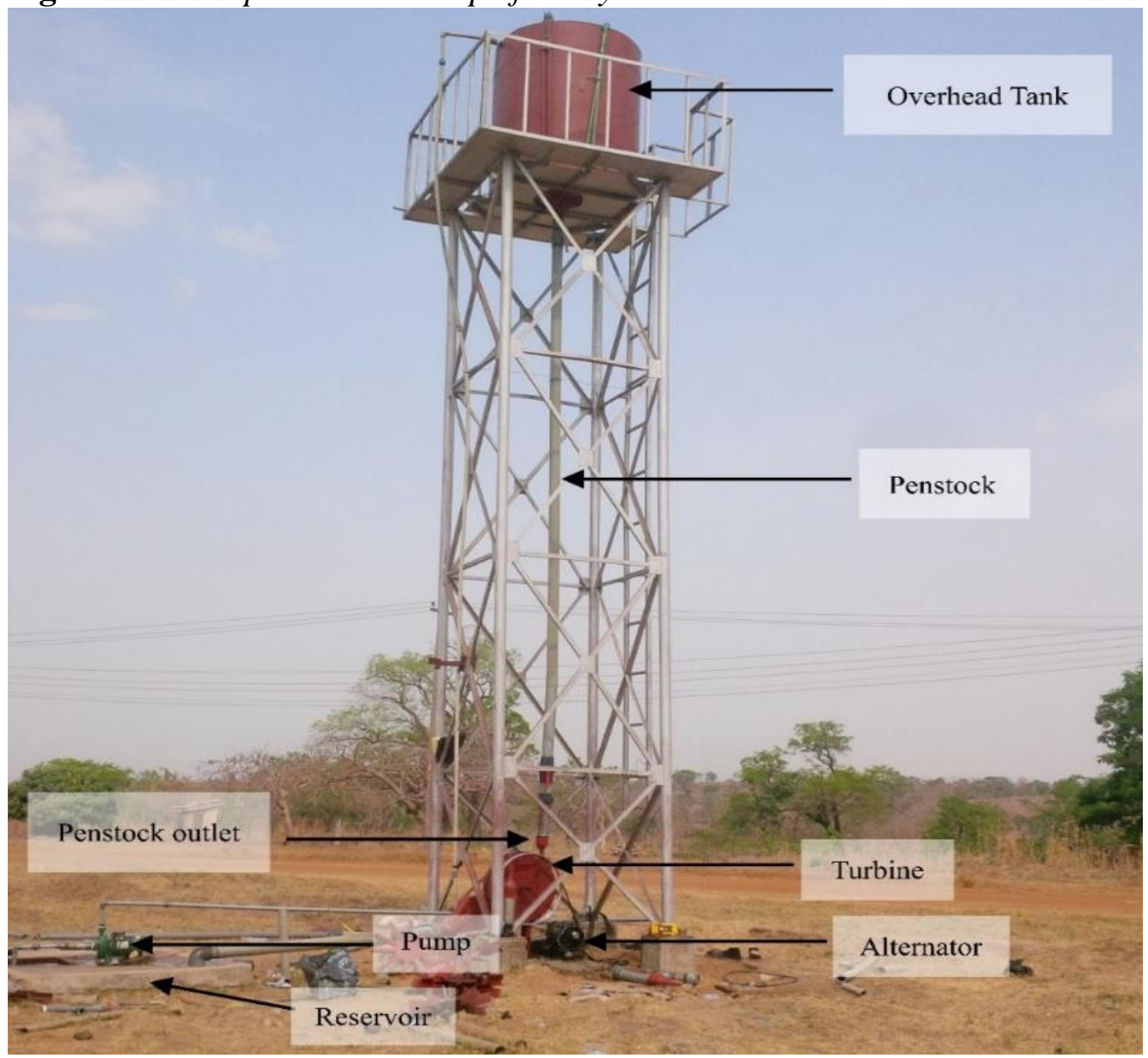

The suction pipe of the pump draws water from the underground reservoir to the overhead tank to create a head. Water is then released from the overhead tank through the penstock and flows through the reduced diameter penstock outlet before impinging on the blades. The flow through the turbine is regulated using a gate valve installed before entry to the penstock. The water jet strikes the blades which are attached to the hub, therefore transferring its kinetic energy to the shaft 
causing the rotary motion of the hub and the shaft assembly which develops a torque. The torque is then transferred to the alternator.

The experimentation was carried out in three batches. First, each number of vblades was tested for each of the penstock outlets. Next, five lateral twist angles of the flat blades of 50, 55, 60, 75 and $90^{\circ}$ were tested against the various penstock outlets. Finally, the runners with varying hub to blade ratio were then tested. For each test, water released by opening the gate valve through the penstock impinges on the blades. The blades are pushed tangentially by the falling water. The thrust produced by the water on the blades produces a torque on the shaft resulting in revolution of the runner. For each, a DT-2268 contact type tachometer was used to measure the rotational speeds of the turbine and alternator shaft speed in revolutions per minute. Also, the water levels in the reservoir and overhead tank before and after each test were monitored with the aid of a calibrated dip stick and each operation was timed using a stopwatch. The difference in water levels for the overhead tank was used to compute the flow rate. The water level in the overhead tank before the flow is used in computing the gross head. The major and minor losses were also computed. The hydraulic power was computed using the rotational speed of the turbine shaft. The results obtained were then correlated at 95\% and a reliability test performed on them using Cronbach's alpha (CA).

\section{Results}

Figures 6 to 8 show the variation of the alternator shaft speed with number of v-blades, angle of twist of flat blades and hub to blade ratio respectively obtained for the respective penstock outlet diameters. Figures 9 to 11 show the variation of the alternator shaft speed with the penstock outlet diameter for the three other parameters.

Figures 12 to 14 show the variation of the system computed power with number v-blades, angle of twist of flat blades and hub to blade ratio respectively for the penstock outlet diameters. Figures 15 to 17 show the variation of the computed power with penstock outlet diameters for the three parameters.

Figure 6. Variation of Alternator Shaft Speed with Number of Blades for the Penstock Outlet Diameters

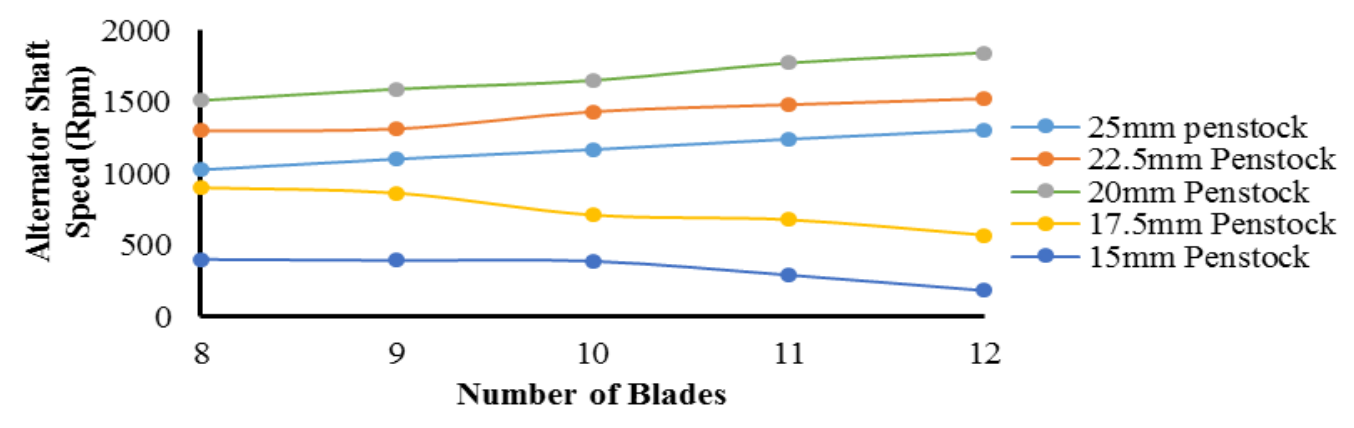


Figure 7. Variation of Alternator Shaft Speed with Blade Lateral Twist Angle

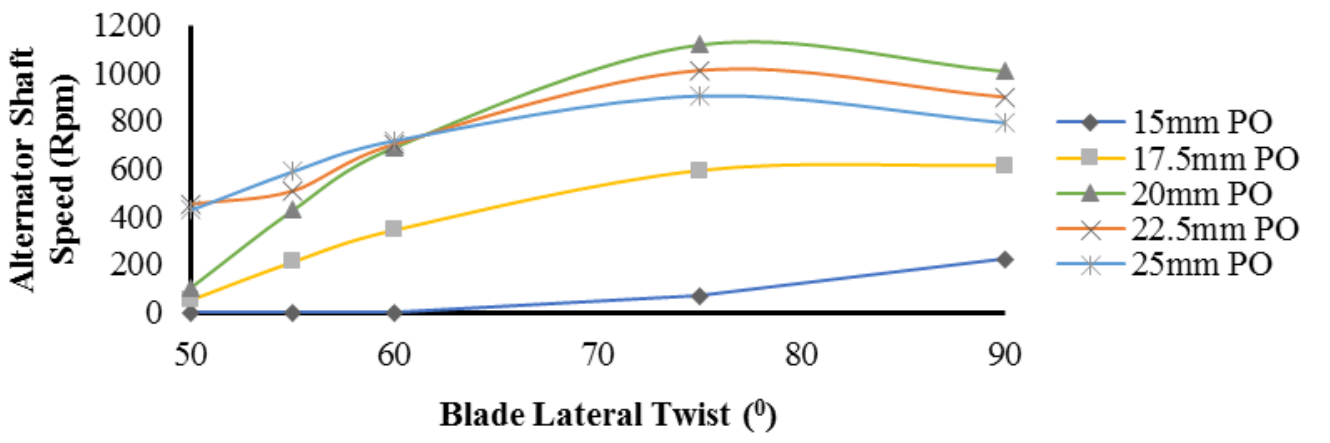

Figure 8. Variation of Alternator Shaft Speed with Turbine Hub to Blade Ratio

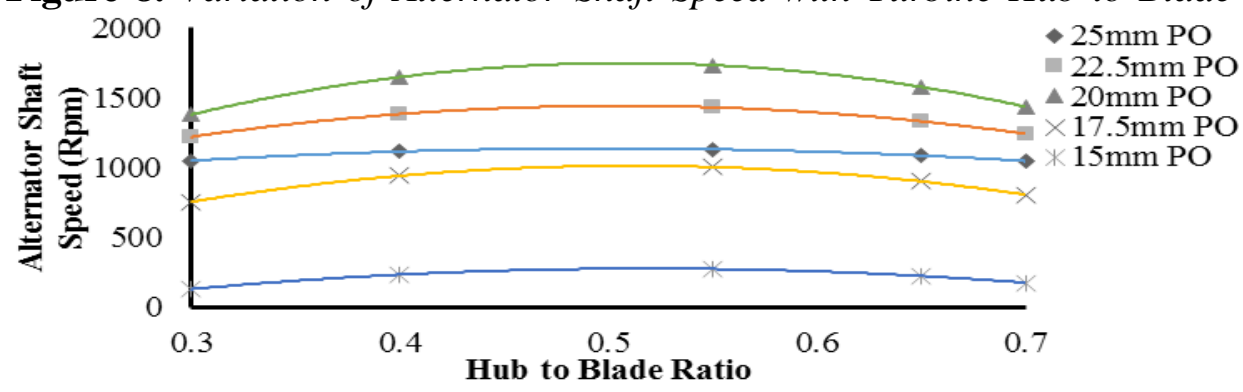

Figure 9. Variation of Alternator Shaft Speed with the Penstock Outlet Diameters for the Various Number of Blades

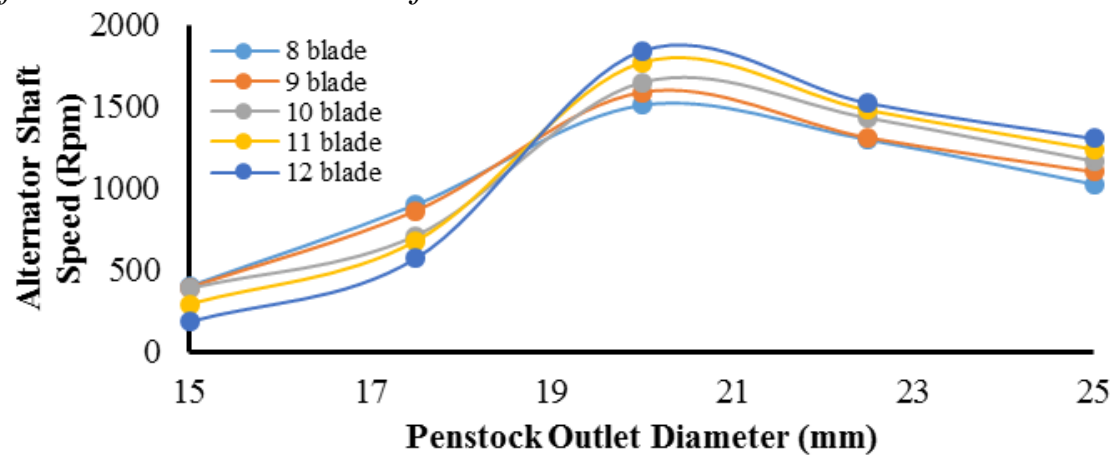

Figure 10. Variation of Alternator Shaft Speed with Penstock Outlet Diameters

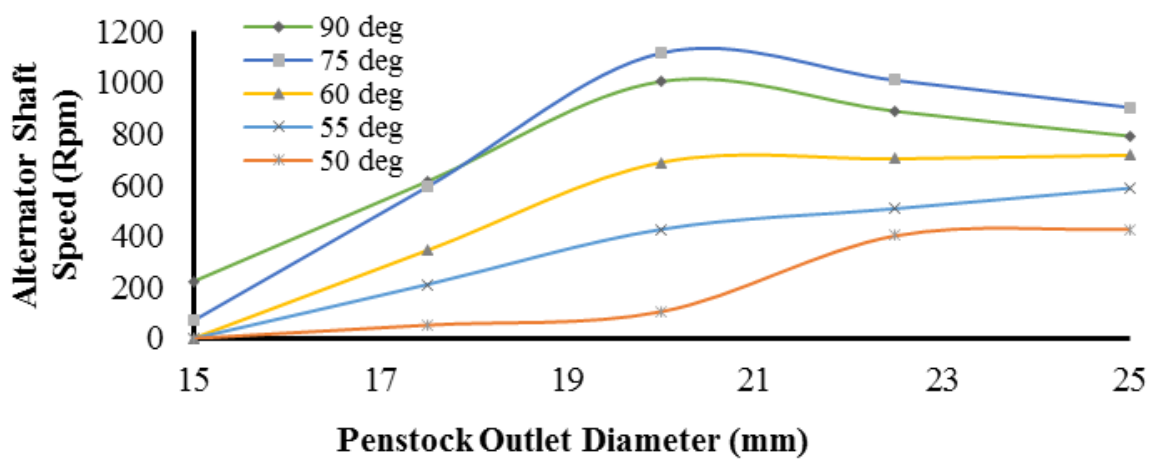


Figure 11. Variation of Alternator Shaft Speed with Penstock Outlet Diameter

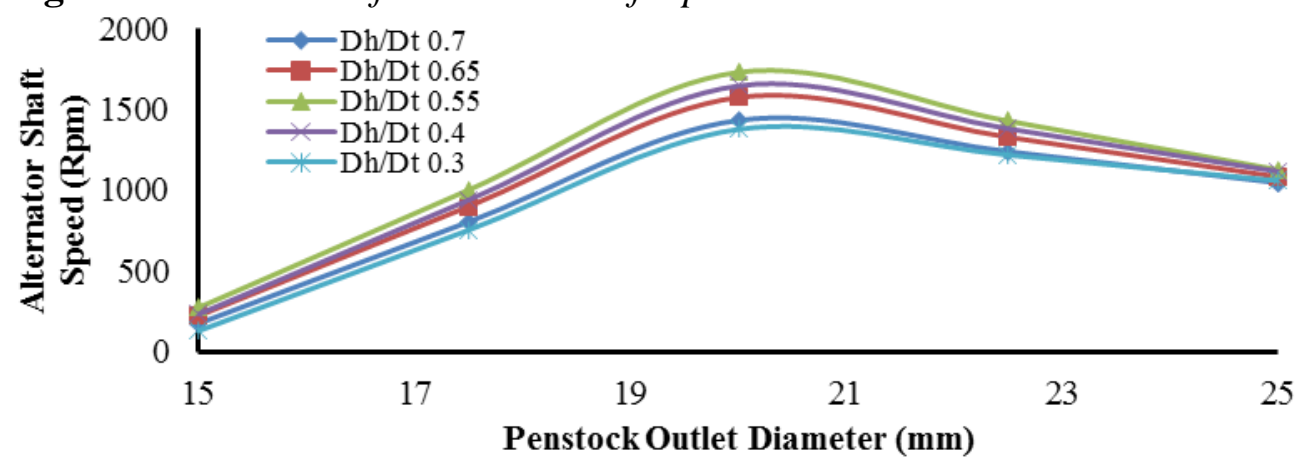

Figure 12. Variation of Computed Power with the Number of Blades for the Penstock Outlet Diameters

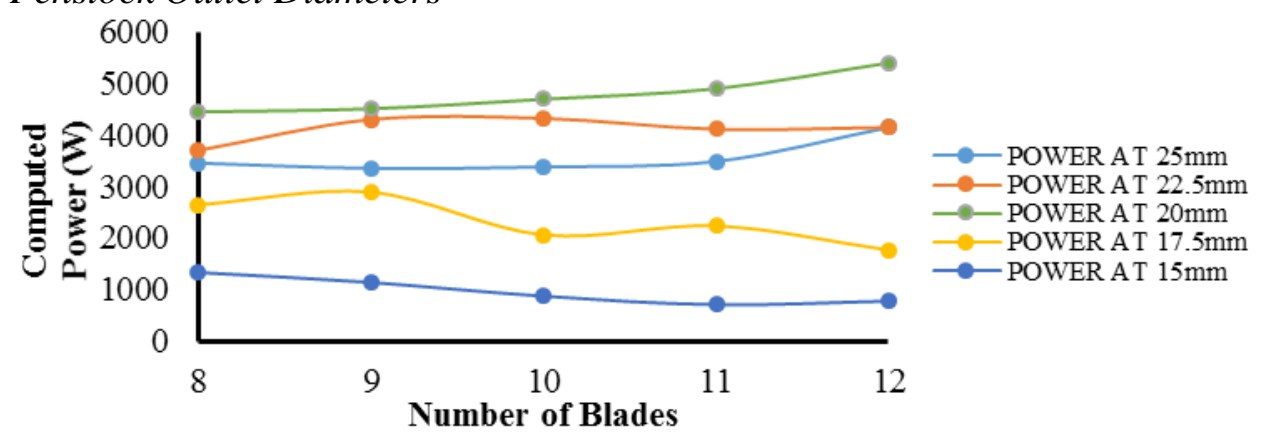

Figure 13. Variation of Computed Power against Blade Lateral Twist Angle

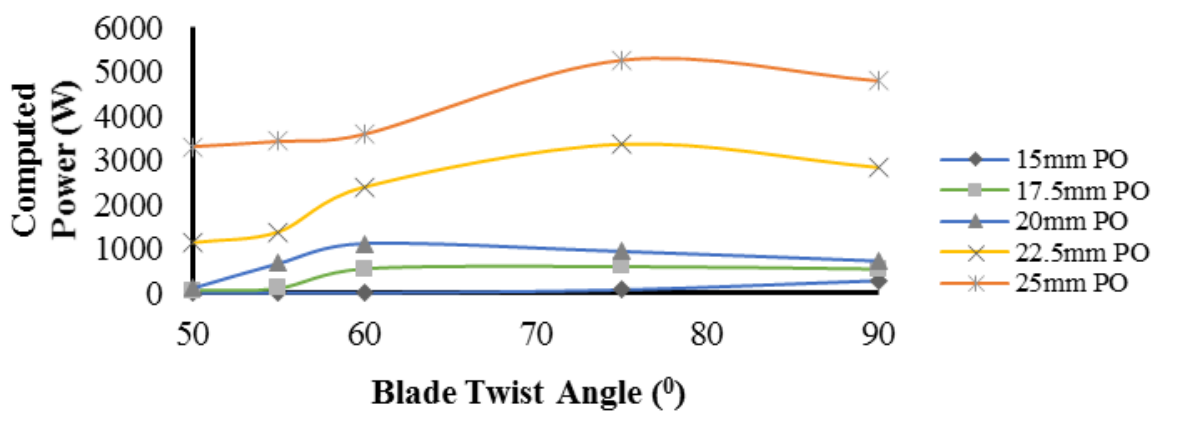

Figure 14. Variation of Computed Power with Turbine Hub to Blade Ratio

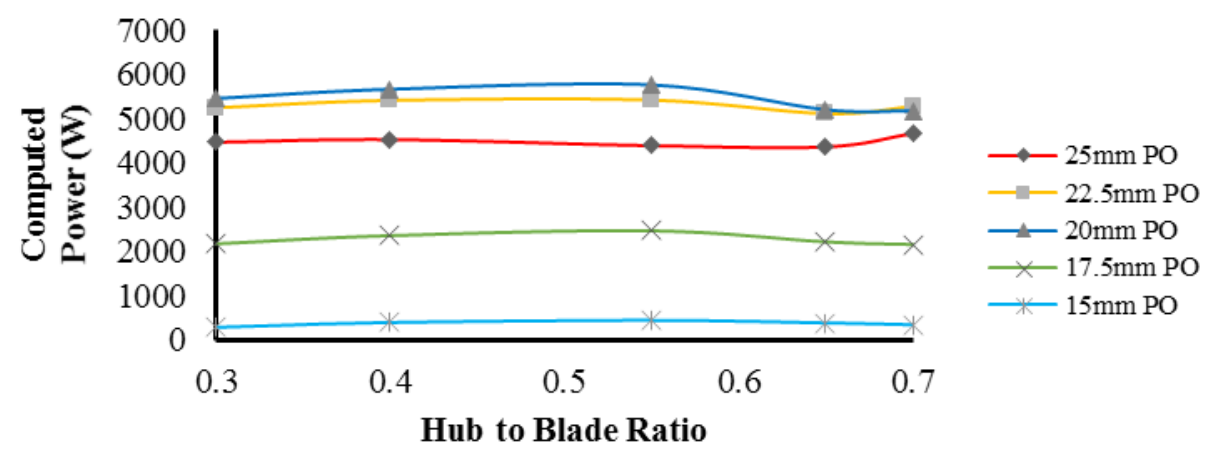


Figure 15. Variation of Computed Power with the Penstock Outlet Diameter for the Number of Blades

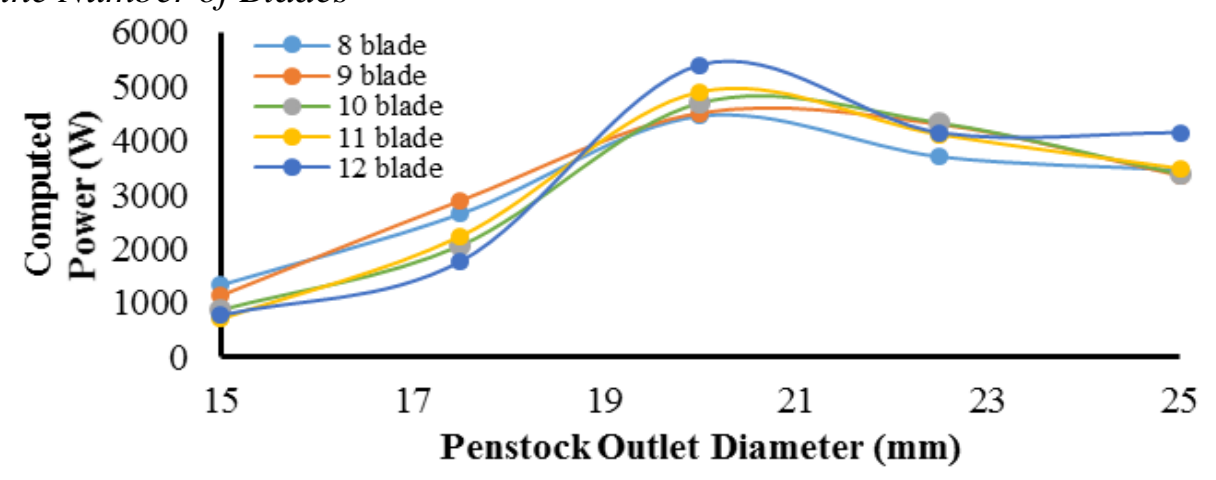

Figure 16. Variation of Computed Power with Penstock Outlet Diameter for the Blade Lateral Twist Angles

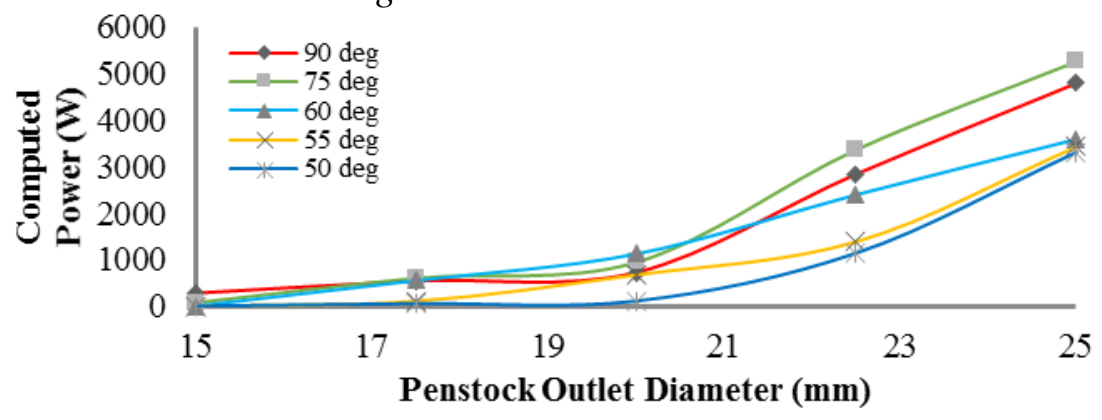

Figure 17. Variation of Computed Power with Penstock Outlet Diameter for the Hub to Blade Ratios

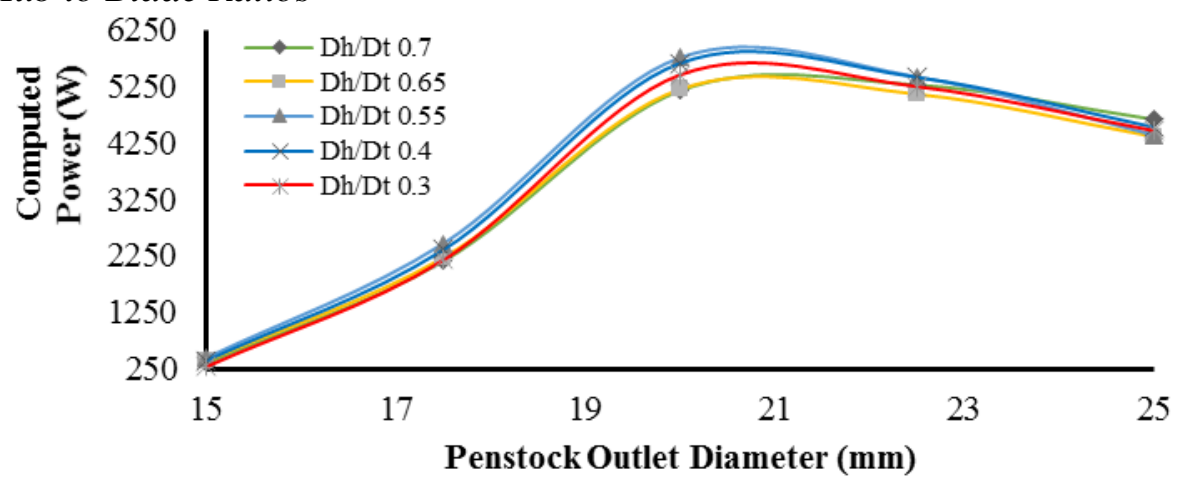

Tables 1 and 2 show the summary of the result of Pearson's correlation test carried out on the data, while Tables 3 to 5 show the summary of the result of the reliability tests carried out on the data using Cronbach's Alpha ( $C A)$. In the tables, apart from the abbreviations already encountered, $N_{T}$ refers to the turbine shaft rotational speed, $N$ the ideal or expected speed of the alternator shaft, $\%$ loss the percentage difference between the actual and ideal alternator shaft speeds and $P$ the computed power. 
Table 1. P-Value of Relationship between the Parameters and Power

\begin{tabular}{|l|c|c|}
\hline Parameters & $\mathbf{N}$ & $\mathbf{P}(\mathbf{W})^{*}$ \\
\hline BHR & 25 & 0.941 \\
\hline BTA & 25 & $(-) 0.263$ \\
\hline NOB & 25 & 0.958 \\
\hline $\mathrm{N}_{\mathrm{T}}(\mathrm{Rpm})$ & 75 & 0.000 \\
\hline $\mathrm{N}_{\mathrm{A}}(\mathrm{Rpm})$ & 75 & 0.000 \\
\hline $\mathrm{N}(\mathrm{Rpm})$ & 75 & 0.000 \\
\hline$\%$ loss & 75 & $(-) 0.133$ \\
\hline
\end{tabular}

*(-) indicates negative correlation.

Table 2. P-Value of Relationship between the Pairs of Parameters

\begin{tabular}{|l|c|c|c|c|c|c|}
\hline Parameters & $\mathbf{N}$ & $\begin{array}{c}\mathbf{N}_{\mathbf{T}} \\
(\mathbf{R p m})\end{array}$ & $\mathbf{N}_{\mathbf{A}}(\mathbf{R p m})$ & $\mathbf{N}(\mathbf{R p m})$ & \% loss & $\mathbf{P}(\mathbf{W})$ \\
\hline POD & 75 & 0.000 & 0.000 & 0.000 & $(-) 0.228$ & 0.000 \\
\hline BHR & 25 & $(-) 0.916$ & $(-) 0.973$ & $(-) 0.827$ & 0.861 & 0.941 \\
\hline BTA & 25 & $(-) 0.005$ & $(-) 0.004$ & $(-) 0.005$ & $(-) 0.152$ & $(-) 0.263$ \\
\hline NOB & 25 & 0.822 & 0.831 & 0.822 & 0.423 & 0.958 \\
\hline$\%$ loss & 75 & $(-) 0.345$ & $(-) 0.006$ & $(-) 0.781$ & - & $(-) 0.133$ \\
\hline
\end{tabular}

Table 3. Reliability of the System on the Number of Blades (NOB) and Other Parameters

\begin{tabular}{|c|c|c|}
\hline Item & Cronbach's Alpha & CA if Item Deleted \\
\hline $\mathrm{P}(\mathrm{W})$ & \multirow{6}{*}{0.692} & 0.662 \\
\hline $\mathrm{N}_{\mathrm{A}}(\mathrm{rpm})$ & & 0.499 \\
\hline $\mathrm{N}(\mathrm{Rpm})$ & & 0.501 \\
\hline$\%$ loss & & 0.724 \\
\hline $\mathrm{N}_{\mathrm{T}}(\mathrm{rpm})$ & & 0.703 \\
\hline $\mathrm{NOB}$ & & 0.721 \\
\hline
\end{tabular}

Table 4. Reliability of the System on the Blade Hub Ratio and Other Parameters

\begin{tabular}{|l|c|c|}
\hline Item & Cronbach's Alpha & CA if Item Deleted \\
\hline $\mathrm{P}(\mathrm{W})$ & \multirow{3}{*}{0.631} & 0.628 \\
\cline { 1 - 1 } $\mathrm{N}_{\mathrm{A}}(\mathrm{rpm})$ & 0.475 \\
\hline $\mathrm{N}(\mathrm{Rpm})$ & & 0.406 \\
\cline { 1 - 1 }$\%$ loss & & 0.658 \\
\hline $\mathrm{N}_{\mathrm{T}}(\mathrm{rpm})$ & & 0.638 \\
\hline BHR & & 0.657 \\
& & \\
\end{tabular}


Table 5. Reliability of the System on the Blade Twist Angle (BTA) and Other Parameters

\begin{tabular}{|c|c|c|}
\hline Item & Cronbach's Alpha & CA if Item Deleted \\
\hline $\mathrm{P}(\mathrm{W})$ & \multirow{6}{*}{0.530} & 0.666 \\
\hline $\mathrm{N}_{\mathrm{A}}(\mathrm{rpm})$ & & 0.384 \\
\hline $\mathrm{N}(\mathrm{Rpm})$ & & 0.299 \\
\hline$\%$ loss & & 0.548 \\
\hline $\mathrm{N}_{\mathrm{T}}(\mathrm{rpm})$ & & 0.530 \\
\hline BTA & & 0.552 \\
\hline
\end{tabular}

\section{Discussion}

Figure 6 to 8 confirm the general expectation that the alternator shaft speed $\left(N_{A}\right)$ improves with increasing flow rate, a function of flow area, which favors the development of higher torques (Edeoja et al. 2016a, Derakhshan and Kasaiean 2012, Park et al. 2012, von Flotow 2012, Smith and Bush 2010). Also, it has been shown for this system that $N_{A}$ increases with the number of blades $(N O B)$ before deteriorating after about 10 to 12 blades (Edeoja et al. 2016c). Figure 6 shows that $N_{A}$ steadily increased with NOB for the range of penstock outlet diameter (POD) of $20 \mathrm{~mm} \leq P O D \leq 25 \mathrm{~mm}$ as against a decrease after $N O B=9$ for $P O D \leq 17.5$ $\mathrm{mm}$. The value for $P O D=20 \mathrm{~mm}$ were generally the highest including the ones within the $20 \mathrm{~mm} \leq P O D \leq 25 \mathrm{~mm}$ range. This confirms the tendency of flow acceleration increasing with area reduction until a turning point is attained depending on the initial area. The values for $P O D=22.5$ and $25 \mathrm{~mm}$ generally agree with the fact that larger diameters support higher flow rates resulting in large values of $N_{A}$ (Tamrakar et al. 2015, Al Amin and Talukder 2014, At-Tasneem 2014, Martins and Sharma 2014, Sangal et al. 2013, Yassi and Hasemloo 2010). Hence, the combination of an optimum $P O D=20 \mathrm{~mm}$ and increasing $N O B$ favors the production of good torque and as a result improved $N_{A}$.

Figure 7 shows that the pattern of variation of $N_{A}$ for the respective PODs was not well defined below blade twist angle (BTA) of $60^{\circ}$. Apart from some likely errors of alignment, this could largely be attributed to insufficient blade surface area of blade available for the water jet to strike. For $B T A \geq 60^{\circ}$ however, for all the values of $P O D, N_{A}$ increased steadily with $B T A$, peaking around $75^{\circ}$ before deteriorating. However, for $P O D=15 \mathrm{~mm}, N_{A}$ did not deteriorate because the reduced flow area was compensated for by the greater blade surface area available for interaction with the water jet. On the whole, $B T A$ varied with $N_{A}$ in the range $20 \mathrm{~mm} \leq P O D \leq 25 \mathrm{~mm}$ in a similar fashion as the case with $N O B$ vis a vis being highest for $P O D=20 \mathrm{~mm}$ followed by $22.5 \mathrm{~mm}$ and the $25 \mathrm{~mm}$. Hence, $B T A \geq$ $75^{\circ}$ and $P O D=20 \mathrm{~mm}$ will favour larger values of $N_{A}$.

Figure 8 shows the variation of hub to blade ratio $(H B R)$ with $N_{A}$. It also generally indicated that $N_{A}$ was higher for the range $20 \mathrm{~mm} \leq P O D \leq 25 \mathrm{~mm}$, with the values for $P O D=20 \mathrm{~mm}$ being also highest followed by the others as before. Also, the general tendency was for $N_{A}$ to peak at $H B R=0.55$ which agrees with the range of values reported by several researchers (Pacayra et al. 2016, 
Williamson et al. 2011, Simpson and Williams 2011, Sopian and Ab Razak 2009). This was not however significant for $P O D=25 \mathrm{~mm}$ probably because the increased flow rate for the larger diameter outlet compensated for all the other values of $H B R$. Hence, $P O D \geq 20 \mathrm{~mm}$ and $H B R=0.55$ favor the development of higher values of $N_{A}$.

Figures 9 to 11 display the variation of $N_{A}$ with $P O D$ for the other three parameters. They generally agree with the foregoing discussions. They respectively show that 12 blades, $B T A \geq 75^{\circ}$ and $H B R=0.55$ along with $P O D=20 \mathrm{~mm}$ favour a good performance in terms of the $N_{A}$ attained. On a general note, high values of $N_{A}$ lead to larger power outputs. Hence, the combination of these parameters yielding high $N_{A}$ should potentially produce large power output.

Figures 12 to 14 show the relationship between the system's computed power with $N O B, B T A$ and $H B R$ for the various PODs. The figures bear some resemblance to Figures 6 to 8 expectedly because the power generated in a conventional hydropower system depends more or less directly on $N_{A}$ (Alnakhlani et al. 2015, Ridzuan et al. 2015, Chukwuneke et al. 2014, Yadav and Chauhan, 2014, Katre and Bapat 2014, Ho-yan 2012, Ho-yan 2011, Pengchang et al. 2006). In Figure 14, however, the variation of the computed power with BTA for $P O D=$ $20 \mathrm{~mm}$ did not resemble the pattern shown in Figure 8 . This probably could have been as a result of some alignment and measurement errors. It was nonetheless above the trends for $P O D \leq 17.5 \mathrm{~mm}$, thereby affirming that the range $20 \mathrm{~mm} \leq$ $P O D \leq 25 \mathrm{~mm}$ favors good system performance. Along with this range of $P O D$, Figure 13 shows that $N O B=12$ yielded the highest computed power of $>5000 \mathrm{~W}$. Also, $B T A \approx 75^{\circ}$ gave the highest computed power for the same range as shown in Figure 14. Figure 15 also indicated slightly that $H B R=0.55$ produced the highest power output though for all values of HBR, the computed power for the range 20 $\mathrm{mm} \leq P O D \leq 22.5 \mathrm{~mm}$ were all $>5000 \mathrm{~W}$.

Figures 15 to 17 show the relationship between the computed power and the PODs for the various NOB, BTA and HBR. They further strengthen the findings reflected in Figures 12 to 14. Hence, for the system, the condition that $20 \mathrm{~mm} \leq$ $P O D \leq 22.5 \mathrm{~mm}, N O B=12, B T A \geq 75^{\circ}$ and $H B R=0.55$, favor large power generation. For the ongoing development of a clean, decentralized and highly simplified energy system, these findings represent very good indications for the actual implementation for end user applications.

Tables 1 and 2 indicate that $B H R, B T A, N O B$ and \% loss have no statistically significant relationship with (or effect on) the power of the system with $p>0.05$. However, $P O D$ has a highly significant effect on the power with $p<0.05$. Furthermore, each of $P O D$ and $B T A$ individually has a highly significant relationship with each of $N_{T}, N_{A}$ and $N$ with $p>0.05$ for each case which in turn individually has a highly significant relationship with power $(p<0.05)$. It is noteworthy that the relationship of BTA with the $\mathrm{N}$-parameters is negative such that as one increases the other is expected to decrease. On the other hand, each of $B H R$ and $N O B$ individually has no statistically significant effect on the $\mathrm{N}$ parameters and \% loss $(p>0.05)$ and hence, on the power of the system. $\%$ loss has no significant relationship with any of the parameters except $N_{A}$. Meanwhile, the relationship is negative such that the lower the former the higher the latter. 
Hence, $N_{A}$ is the most critical of all N-parameters, agreeing with what has been established earlier on in the discussion. High $N_{A}$ is desired for high power and low $\%$ loss. In order of preference, high $P O D$ is desired for increasing both $N_{A}$ and power followed by lowering $B T A$ for increasing $N_{A}$. BHR and $N O B$ have no statistically significant consequences at this level.

Cronbach's alpha $(C A)$ is used to test the extent of reliability of the performance of the system on the parameters. When $C A>0.05$, it means that a statistically highly significant reliability level exists. The value of $C A$ when a parameter is removed from the system is also given as shown in Tables 3 to 5 . From the tables, the performance of the system has a highly significant reliability on the $N O B, B H R$ and $B T A$ combined with other identical parameters because of their high $C A$ values of $0.692,0.631$ and 0.530 respectively. This is indicated from the respective values of turbine and hence alternator shaft speeds. Low values of these parameter result in reduction in $C A$ values. This means that the system performance most highly relies on the value of these parameters. Also, $C A$ would be highly improved when $\%$ loss is reduced in the system. Hence, the performance least significantly relies on $\%$ losses and so, all effort must be made to remove $\%$ losses. However, since the $C A$ value when each of $N O B, B H R$ and BTA are respectively removed from the system is only higher for $B T A$ than when $\%$ loss is removed in Table 5, it implies that the system performance relies more on BTA than $\%$ loss with the reverse is applicable for $B H R$ and $N O B$. Hence, $N_{A}$ and $N$ are very critical to the performance of the system. They must not be removed. \% loss must be removed from the system to improve the performance. Also, the performance of the system significantly relies on $N O B, B H R$ and BTA. However, the reliability of the systems improves when either is removed from the system. On the whole, a perfect match exists between the conclusions drawn from the two tests.

\section{Conclusions}

Based on the results obtained from the study, the following conclusions can be drawn for further development of the system with a view of improving performance and achieving end user status for small scale power generation:

1. For the v-blades configuration this particular Pico-hydro system, a $20 \mathrm{~mm}$ penstock outlet diameter with a 12 blade runner is appropriate for use.

2. The combination of flat blade twist angles in the range $75^{\circ} \leq \theta<90^{\circ}$ with penstock outlet diameters in the range $>20 \mathrm{~mm}$ have very good potential for use on the Pico hydropower system with possibility for scaling to suit specific requirements for system performance.

3. In addition to the issues raised, the study also confirms that the hub to blade ratio of 0.55 is appropriate for this system.

The findings strengthens the resolve to keep striving in order to actualize the target of adding this system as an end user energy solution which is clean, 
environmentally benign and less vulnerable to sabotage into the energy mix in Nigeria. The following recommendations/suggestions are made for further improvement of the performance of the simplified Pico hydro system:

1. Turbine casings used should have adequate provision for the runner not to run through the water so that drag forces on it can be minimized.

2. The effects of water jet misalignments will be further reduced by incorporating provision(s) for such in further designs.

3. Larger diameter pipes should be used in transferring water to the overhead tank to sustain the flow circle at the expense of justifiable higher cost.

4. Larger and/or multiple reservoirs will also be explored to enhance the robustness of the system.

5. Lighter metals such as aluminum should be used in fabricating the runners and blades as heavier metals like mild steel add to the inertia and thus decrease turbine performance.

6. The option of hybridization with solar energy is very viable in the location of the work and will be explored with better access to funding.

Most importantly, a general awareness and technical understanding of successful Pico-hydro technology needs to be developed and fostered at the local and regional levels so that rural electrification projects can be boosted.

\section{Acknowledgments}

Our thanks go to the entire staff of the Mechanical Engineering Workshop for their consistent contributions in the various fabrication processes that the work demanded. We also thank Engr. T. Agana, Mr. Ken Edo and Mr. Tersoo Uor of the University Water Works for their selfless contributions in all the plumbing work and supply of water, including the purchases, monitoring of data and several adjustments done during the course of the work.

\section{References}

Adamkowski A. (2012) Discharge Measurement Techniques in Hydropower Systems with Emphasis on the Pressure-Time Method, Hydropower - Practice and Application. In Hossein Samadi-Boroujeni (ed), In Tech. ISBN: 978-953-51-0164-2.

Adejumobi IA, Adebisi OI, Oyejide SA (2013) Developing Small Hydropower Potentials for Rural Electrification. IJRRAS 17(1): 105-110.

Ajuwape T, Ismail OS (2011) Design and Construction of a 5kW Turbine for a Proposed Micro Hydroelectric Power Plant Installation at Awba Dam University of Ibadan. International Journal of Electrical and Power Engineering 5(3): 131-138.

Akuru UB, Okoro OI (2011) A Prediction on Nigeria's Oil Depletion Based on Hubbert's Model and the Need for Renewable Energy. ISRN Renewable Energy 2011(Sep) Article ID 285649. 
Al Amin R, Talukder, AH (2014) Introducing Pico Hydro from Daily Used Water and Rain Water, International Journal of Engineering Research and Applications 4(1-2): 382-385.

Alexander KV, Giddens EP (2008a) Optimum Penstocks for Low Head Micro Hydro Schemes. Renewable Energy 33(3): 507-519.

Alexander KV, Giddens EP (2008b) Micro Hydro: Cost-Effective, Modular Systems for Low Heads. Renewable Energy 33(6): 1379-1391.

Alexander KV, Giddens EP, Fuller AM (2009a) Axial-Flow Turbines for Low Head Micro Hydro Systems. Renewable Energy 34(1): 35-47.

Alexander KV, Giddens EP, Fuller AM (2009b) Radial- and Mixed-Flow Turbines for Low Head Microhydro Systems. Renewable Energy 34(7): 1885-1894.

Alnakhlani MM, Mukhtar DA, Himawanto AA, Danardono D (2015) Effect of the Bucket and Nozzle Dimension on the Performance of a Pelton Water Turbine. Modern Applied Science 9(1): 25-33.

Amor MB, Pineau P, Gaudreault C, Samson R (2011) Electricity Trade and GHG Emissions: Assessment of Quebec's Hydropower in the North-Eastern American Market (2006-2008). Energy Policy 39(3): 1711-1721.

Arto I, Capellán-Pérez I, Lago R, Bueno G, Bermejo R (2016) The Energy Requirements of a Developed World. Energy for Sustainable Development 33(Aug): 1-13.

Aslani A. (2013) Private Sector Investment in Renewable Energy Utilization: Strategic Analysis of Stakeholder Perspectives in Developing Countries. International Journal of Sustainable Energy 33(1): 1-13.

At-Tasneem MA, Azam WM, Jamaludin U (2014) A Study on the Effect of Flow Rate on the Power Generated by a Pico Hydro Power Turbine. World Applied Sciences Journal 30(Jun): 420-423.

Bala EJ (2013a) Renewable Energy and Energy Efficiency Development in Nigeria. Keynote Paper at the 2-Day Workshop on Renewable Energy and Energy Efficiency, $10^{\text {th }}-11^{\text {th }}$ June, 2013. Awka: Nnamdi Azikiwe University.

Bala EJ (2013b) Achieving Renewable Energy Potential in Africa. Joint WEC, AUC and APUA Workshop, $17^{\text {th }}-18^{\text {th }}$ June, 2013. Addis Ababa, Ethiopia.

Baumann P, Stevanella G (2012) Fish Passage Principles to be Considered for Medium and Large Dams: The Case Study of a Fish Passage Concept for a Hydroelectric Power Project on the Mekong Mainstream in Laos. Ecological Engineering 48(Nov): 79-85.

Bergasse E, Paczynski W, Dabrowski M, Dewulf L (2013) The Relationship between Energy and Socio-Economic Development in the Southern and Eastern Mediterranean. MEDPRO Technical Report No. 27/February.

Bohlen C, Lewis LY (2009) Examining the Economic Impacts of Hydropower Dams on Property Values Using GIS. Journal of Environmental Management 90(Jul): S258S269.

British Petroleum (2016) BP Energy Outlook 2016 Edition: Outlook to 2035. 44, 74-77, 90-94. Retrieved from www.bp.com/energyoutlook\#BPstats.

British Petroleum (2017) BP Energy Outlook 2017 Edition. 9-22, 74-77, 90-94. Retrieved from www.bp.com/energy outlook\#BPstats.

Chanudet V, Descloux S, Harby A, Sundt H, Hansen BH, Brakstad O, Serça D, Guerin F (2012) Gross $\mathrm{CO}_{2}$ and $\mathrm{CH}_{4}$ Emissions from the Nam Ngum and Nam LeukSubTropical Reservoirs in Lao PDR. Science of the Total Environment 409(24): 53825391.

Cheng C, Shen J, Wu X, Chau K (2012) Operation Challenges for Fast-Growing China's Hydropower Systems and Respondence to Energy Saving and Emission Reduction. Renewable and Sustainable Energy Reviews 16(5): 2386-2393. 
Choi Y, Lee C, Song J (2017) Review of Renewable Energy Technologies Utilized in the Oil and Gas Industry. International Journal of Renewable Energy Research 7(2): 592-598.

Chuenchooklin S (2006) Development of Pico-hydropower Plant for Farming Village in Upstream Watershed, Thailand. Prosperity and Poverty in a Globalised World Challenges for Agricultural Research. Tropentag, October 11-13, Bonn.

Chukwuneke JL, Achebe CH, Okolie PC, Okwudibe HA (2014) Experimental Investigation on the Effect of Head and Bucket Splitter Angle on the Power Output of a Pelton Turbine. Journal of Information Engineering and Applications 4(10): 48-54.

Cobb BR (2011) Experimental Study of Impulse Turbines and Permanent Magnet Alternators for Pico-Hydropower Generation. MSc Thesis. Department of Mechanical Engineering, Oregon State University.

Cobb BR, Sharp KV (2013) Impulse Turbine Performance Characteristics and Their Impact on Pico-Hydro Installations. Renewable Energy 50(Feb): 959-964.

Cunbin L, Xian L, Minxia W (2012) Risk Analysis Simulation Model of Economic Evaluation in Hydroelectric Engineering Project. Research Journal of Applied Sciences, Engineering and Technology 4(14): 2222-2226.

Deng Z, Carlson TJ, Dauble DD, Ploskey GR (2011) Fish Passage Assessment of an Advanced Hydropower Turbine and Conventional Turbine Using Blade-Strike Modelling. Energies 4(1): 57-67.

Deng ZD, Martinez JJ, Colotelo AH, Abel TK, LeBarge AP, Brown RS, Pflugrath, BD, Mueller RP, Carlson TJ, Seaburg AG, Johnson RL, Ahmann ML (2012) Development of External and Neutrally Buoyant Acoustic Transmitters for Juvenile Salmon Turbine Passage Evaluation. Fisheries Research 113(1): 94-105.

Derakhshan S, Kasaeian N (2012) Optimal Design of Axial Hydro Turbine for Micro Hydropower Plants. $26^{\text {th }}$ IAHR Symposium on Hydraulic Machinery and Systems, IOP Conference Series: Earth and Environmental Science 15(4): 2029.

Economic Consulting Associates - ECA (2014) Correlation and Causation between Energy Development and Economic Growth. Economic Consulting Associates.

Edeoja AO, Ibrahim JS, Kucha EI (2015a) Suitability of Pico-Hydropower Technology for Addressing the Nigerian Energy Crisis - A Review. International Journal of Engineering Inventions 4(9): 17-40.

Edeoja AO, Ibrahim JS, Kucha EI (2015b) Conceptual Design of a Simplified Decentralized Pico Hydropower with Provision for Recycling Water. Journal of Multidisciplinary Engineering Science and Technology 2(2): 22-34.

Edeoja AO, Ibrahim JS, Kucha EI (2016a) Investigation of the Effect of Penstock Configuration on the Performance of a Simplified Pico-Hydro System. British Journal of Applied Science \& Technology 14(5): 1-11.

Edeoja AO, Ibrahim JS, Tuleun LT (2016b) Effect of Blade Cross-Section on the Performance of a Simplified Pico-Hydro System. American Journal of Engineering Research 5(12): 1-9.

Edeoja AO, Edeoja JA, Ogboji ME (2016c) Effect of Number of Turbine Runner VBlades on the Performance of a Simple Pico-Hydro System. Accepted for publication in International Journal of Engineering and Technology, Reference Number 316145147726833.

Edeoja AO, Awuniji L (2017) Experimental Investigation of the Influence of Penstock Configuration and Angle of Twist of Flat Blades on the Performance of a Simplified Pico-Hydro System. EJERS, European Journal of Engineering Research and Science 2(7): 14-22. 
Edeoja AO, Edeoja JA, Ogboji ME (2017) Effect of Included Angle of V-Shaped Blades on the Performance of a Simplified Pico-Hydro System. International Journal of Scientific and Engineering Research 8(8): 1208-1213.

Edomah N (2016) On the Path to Sustainability: Key Issues on Nigeria's Sustainable Energy Development. Energy Reports 2(Nov): 28-34.

Finardi EC, Suzzanto MR (2013) Hydro Unit Commitment and Loading Problem for DayAhead Operation Planning Problem. Electrical Power and Energy Systems 44(1): 716.

Fjeldstad HP, Uglem I, Diserud OH, Fiske P, Forseth T, Kvingedal E, Hvidsten NA, Økland F, Järnegren J (2012) A Concept for Improving Atlantic Salmon Salmo SalarSmolt Migration Past Hydro Power Intakes. Journal of Fish Biology 81(2): 642663.

Gatte MT, Kadhim RA (2012) Hydro Power. In AZ Ahmed (ed), Energy Conservation. Published by In Tech Janeza Trdine 9, 51000. Rijeka, Croatia, 95-124. Retrieved from www.intechopen.com.

Goodland R (2010) Viewpoint-The World Bank versus the World Commission on Dams. Water Alternatives 3(2): 384-398.

Haidar MA, Senan FM, Noman A, Taha R (2012) Utilization of Pico Hydro Generation in Domestic and Commercial Loads. Renewable and Sustainable Energy Reviews 16(1): 518-524.

Ho-Yan B (2011) Tesla Turbine for Pico Hydro Applications. Guelph Engineering Journal 4(Jan): 1-8.

Ho-Yan B (2012) Design of a Low Head Pico Hydro Turbine for Rural Electrification in Cameroon. Thesis Presented to the University of Guelph, Canada. Retrieved from https://dspace.lib.uoguelph.ca/xmlui/handle/ 10214/3552.

Horlacher H, Heyer T, Ramos CM, da Silva MC (2012) Management of Hydropower Impacts through Construction and Operation. Comprehensive Renewable Energy 6(May): 49-91.

Hossain E, Perez R, Bayindir R (2017) Implementation of Hybrid Energy Storage Systems to Compensate Microgrid Instability in the Presence of Constant Power Loads. International Journal of Renewable Energy Research 7(2).

Hussey K, Pittock J (2012) The Energy-Water Nexus: Managing the Links between Energy and Water for a Sustainable Future. Ecology and Society 17(1): 31-39.

International Energy Agency - IEA (2007) World Energy Outlook 2007 Edition. Retrieved from www.iea.org/t\&c/.

International Energy Agency - IEA (2015) World Energy Outlook. 1-12. Retrieved from www.iea.org/t\&c/.

Ipilakyaa DT, Edeoja AO, Kulugh A (2017) Influence of Penstock Outlet Diameter and Flat Blade Lateral Twist Angle on the Performance of a Simplified Pico Hydropower System. International Journal of Trend in Scientific Research and Development 1(5): 394-406.

Islar M (2012) Privatized Hydropower Development in Turkey: A Case of Water Grabbing? Water Alternatives 5(2): 376-391.

Jager HI, Smith BT (2008) Sustainable Reservoir Operation: Can We Generate Hydropower and Preserve Ecosystem Values? River Research and Application 24(3): 340-352.

Jia-Kun LI (2012) Research on Prospect and Problem for Hydropower Development of China. International Conference on Modern Hydraulic Engineering, Procedia Engineering 28(Feb): 677-682. 
Katre SS, Bapat VN (2014) Review of Literature on Induction Generators and Controllers for Pico Hydro Applications. International Journal of Innovations in Engineering Research and Technology 1(1): 1-9.

Kaunda CS, Kimambo CZ, Nielsen TK. (2012) Potential of Small-Scale Hydropower for Electricity Generation in Sub-Saharan Africa. ISRN Renewable Energy 12(Jun) Article ID 132606.

Kumar A, Biswas A (2017) Techno-Economic Optimization of a Stand-Alone PV/PHS/Battery Systems for Very Low Load Situation. International Journal of Renewable Energy Research 7(2): 848-856.

Lahimer V, Alghoul M, Sopian KB, Fadhel MI (2012) Research and Development Aspects of Pico-Hydro Power. Renewable and Sustainable Energy Reviews 16(8): 5861-5878.

Lajqi S, Lajqi N, Hamidi B (2016) Design and Construction of Mini Hydropower Plant with Propeller Turbine. International Journal of Contemporary Energy 2(1): 1-13.

Lior N (2010) Sustainable Energy and Development: The Present (2009) Situation and Possible Path for the Future. Energy 35(10): 3976-3994.

Lipu MSH, Hafiz MG, Ullah MS, Hossain A, Munia FY (2017) Design Optimization and Sensitivity Analysis of Hybrid Renewable Energy Systems: A Case of Saint Martin Island in Bangladesh. International Journal of Renewable Energy Research 7(2): 988-998.

Liu L, Chen H, Yuan X, Chen Z, Wu Y (2011) Unexpected $\mathrm{CH}_{4}$ Emission from the Three Gorges Reservoir and its Implications. Acta Ecologica Sinica 31(5): 233-234.

Liu P, Nguyen T, Cai X, Jiang X (2012) Finding Multiple Optimal Solutions to Optimal Load Distribution Problem in Hydropower Plant. Energies 5(5): 1413-1432.

Liu H, Masera D, Esser L (Eds.) (2013a) World Small Hydropower Development Report 2013 Executive Summary. United Nations Industrial Development Organization; International Center on Small Hydro Power, 1-24.

Liu H, Masera D, Esser L (Eds.) (2013b) World Small Hydropower Development Report 2013. United Nations Industrial Development Organization; International Center on Small Hydro Power, 1-6.

Maher P, Smith N (2001) Pico Hydro for Village Power - A Practical Manual for Schemes up to $5 \mathrm{~kW}$ in Hilly Areas. Micro Hydro Centre, Nottingham University. Retrieved from www.eee.nottingham.ac.uk.

Maher P (2002a) Kenya Case Study 1 at Kathamba and Case Study 2 at Thima. Retrieved from http://www.eee.nottingham.ac.uk/picohydro/documents.html\#kenya.

Maher P (2002b) Design and Implementation of a $2.2 \mathrm{~kW}$ Pico Hydro Serving 110 Households. Micro Hydro Centre - Nottingham Trent University. Retrieved from http://www. eee.nottingham.ac.uk/picohydro/documents.html.

Maher P, Smith N, Williams A (2003) Assessment of Pico Hydro as an Option for Off Grid Electrification in Kenya. Renewable Energy 28(9): 1369-1369.

Martin S, Sharma AK (2014) Analysis on Rainwater Harvesting and its Utilization for Pico Hydro Power Generation. International Journal of Advanced Research in Computer Engineering \& Technology 3(6): 2121-2126.

MDGs 2015. Nigeria 2015 - Millennium Development Goals End point Report. www.mdgs.gov.ng.

Melikoglu M (2013) Vision 2023: Feasibility Analysis of Turkey's Renewable Energy Projection. Renewable Energy 50(Feb): 570-575.

Miller VB, Landis AF, Schaefer LA (2011) A Benchmark for Life Cycle Air Emissions and Life Cycle Impact Assessment of Hydrokinetic Energy Extraction Using Life Cycle Assessment. Renewable Energy 36(3): 1040 -1046. 
Mishra S, Singal SK, Khatod DK (2011a) Optimal Installation of Small Hydropower Plant - A Review. Renewable and Sustainable Energy Reviews 15(8): 3862-3869.

Mishra S, Singal SK, Khatod DK (2011b) Approach for Cost Determination of ElectroMechanical Equipment in RoR SHP Projects. Smart Grid and Renewable Energy, 2(2): 63-67.

Mustonen SM (2010) Rural Energy Survey and Scenario Analysis of Village Energy Consumption: A Case Study in Lao People's Democratic Republic. Energy Policy 38(2): 1040-1048.

Newell P, Phillips J (2016) Neoliberal Energy Transitions in the South: Kenyan Experiences. Geoforum 74(Aug): 39-48.

Nguyen VH, Topno S, Balingbing C, Nguyen VCN, Röder M, Quilty J, Jamieson C, Thornley P, Gummert M (2016) Generating a Positive Energy Balance from Using Rice Straw for Anaerobic Digestion. Energy Reports 2(Nov): 117-122.

Nikolaisen P (2015) 12 Mega Dams that Changed the World but not Necessarily for the Better. http://www.tu.no/artikler/12-megadammer-som-endret-verden/ 223528.

Nimje AA, Dhanjode G (2015) Pico-Hydro-Plant for Small Scale Power Generation in Remote Villages. Ver. III. IOSR Journal of Environmental Science, Toxicology and Food Technology 9(1): 59-67.

Obande AO, Abikoye BO, Amiolemhen PE (2017) The Use of Brewer's Spent Grain as an Effective Energy-Mix Strategy. International Journal of Engineering and Technology 7(4).

Ohunakin OS, Ojolo SJ, Ajayi OO (2011) Small Hydropower (SHP) Development in Nigeria. Renewable and Sustainable Energy Reviews 15(4): 2006-2013.

Okonkwo EC, Okwose CF, Abbasoglu S (2017) Techno-Economic Analysis of the Potential Utilization of a Hybrid PV-Wind Turbine System for Commercial Buildings in Jordan. International Journal of Renewable Energy Research 7(2): 908914.

Olukanmi DO, Salami AW (2012) Assessment of Impact of Hydropower Dams Reservoir Outflow on the Downstream River Flood Regime - Nigeria's Experience. In Dr. Hossein Sammad-Boroujeni (ed), Hydropower-Practice and Application. Retrieved from https://bit.ly/2SFKV69.

Olusegun HD, Adekunle AS, Ohijeagbon IO, Oladosu OA, Ajimotokan HA (2010) Retrofitting a Hydropower Turbine for the Generation of Clean Electrical Power. USEP: Journal of Research Information in Civil Engineering 7(2): 61-69.

Omprasad G (2016) Power Sector Components, Development, and Reforms: An Overview. International Journal of Development Research 6(6): 8156-8163.

Oseni MO (2012) Households' Access to Electricity and Energy Consumption Pattern in Nigeria. Renewable and Sustainable Energy Reviews 16(1): 990-995.

Othman MM, Razak AJ, Basar M, Muhammad N, Wan Mohammad W, Sopian K (2015) A Review of the Pico-Hydro Turbine: Studies on the Propeller Hydro Type. International Review of Mechanical Engineering 9(6): 527-535.

Pacayra N, Sabate C, Villalon A (2016) Assessment of Streams in Oras, Eastern Samar: A Basis for the Design of Pico- hydro Projects and Potential Site for Installation. Imperial Journal of Interdisciplinary Research 2(12): 1083-1088.

Park JH, Lee NJ, Wata JV, Hwang YC, Kim YT, Lee YH (2012) Analysis of a Pico Hydro Turbine Performance by Runner Blade Shape Using CFD. 26 ${ }^{\text {th }}$ IAHR Symposium on Hydraulic Machinery and Systems IOP Publishing IOP Conference Series: Earth and Environmental Science 15(2012): 042031.

Pascale A, Urmee T, Moore A (2011) Life Cycle Assessment of a Community Hydroelectric System in Rural Thailand. Renewable Energy 36(11): 2799-2808. 
Paun D, Paun CA (2017) The Impact of Renewable Energy on the Price of Energy in Romania. International Journal of Renewable Energy Research 7(2): 540-546.

Pengcheng G, Xingqi L, Weili L, Xiaobo Z, Peng L (2006) Effect of Blade Geometric Parameters on the Operating Stability of the Hydraulic Turbine. $4^{\text {th }}$ WSEAS International Conference on Fluid Mechanics and Aerodynamics. Elounda, Greece, 315-318.

Pirlogea C, Cicea C (2012) Econometric Perspective of the Energy Consumption and Economic Growth Relation in European Union. Renewable and Sustainable Energy Reviews 16(8): 5718-5726.

Portale E, de Wit J (2014) Tracking Progress toward Providing Sustainable Energy for All in Middle East and North Africa. World Bank Group. Retrieved from https://bit.ly/2Hcfoqp.

Ramos HM, Simão M, Kenov KN (2012) Low-Head Energy Conversion: A Conceptual Design and Laboratory Investigation of a Microtubular Hydro Propeller, 1-10. International Scholarly Research Network (ISRN), Mechanical Engineering.

REN21 (2014) Renewables 2014 Global Status Report. 13, 17, 21, 25. Paris: REN21 Secretariat. Retrieved from www.ren21.net.

REN21 (2016) Renewables 2016 Global Status Report. Paris: REN21 Secretariat. Retrieved from www.ren21.net.

Ribal A, Amir A. K., Toaha S, Kusuma J, Khaeruddin K (2017) Tidal Current Energy Resource Assessment around Buton Island, Southeast Sulawesi, Indonesia. International Journal of Renewable Energy Research 7(2): 857-865.

Ridzuan MJM, Hafis SM, Azduwin K, Firdaus KM, Zarina Z (2015) Development of Pico-Hydro Turbine for Domestic Use. Applied Mechanics and Materials 695(Sep): 408-412.

Saatci M, Dumrul Y (2013) The Relationship between Energy Consumption and Economic Growth: Evidence from a Structural Break Analysis for Turkey. International Journal of Energy Economics and Policy 3(1): 20-29.

Sambo AA (2005) Renewable Energy for Rural Development: The Nigerian Perspective, ISESCO Science and Technology Vision 1(May): 12-22.

Sambo AA (2008a) The Role of Energy in Achieving Millennium Development Goals $(M D G s)$. Keynote Address at the National Engineering Technology Conference (NETec) $1^{\text {st }}$ April, 2008. Ahmadu Bello University, Zaria.

Sambo AA (2008b) Overview of Policy Landscape in Africa on SHP Project Development and Management. Paper Presented at International Hydropower Conference, Abuja.

Sambo AS (2008c) Matching Electricity Supply with Demand in Nigeria. International Association for Energy Economics. ${ }^{\text {th }}$ Quarter 2008, 32-36.

Samy MM (2017) Techno-Economic Analysis of Hybrid Renewable Energy Systems for Electrification of Rustic Area in Egypt. Innovative Systems Design and Engineering 8(1): 42-54.

Sangal S, Arpit G, Dinesh K (2013) Review of Optimal Selection of Turbines for Hydroelectric Projects. International Journal of Emerging Technology and Advance Engineering 3(3): 424-430.

Science for Environment Policy - SEP (2013) Relationships between Energy Consumption and Economic Growth Investigated. European Commission DG Environment News Alert Service. Bristol: University of the West of England. Retrieved from http://ec.europa.eu/ environment/integration/research/newsalert/pdf/312na6_en.pdf.

Shezi L (2015) Nearly 60\% of Africans Have no Access to Reliable Electricity. Hypertext. Retrieved from http://www.htxt.co.za/2015/05/08/nearly-60-of-africans-have-noaccess-to-reliable-electricity/. 
Shittu J (2015) Towards Achieving Sustainable Development for All: Prioritizing Targets for Implementation: Which Way Forward for Nigeria? Center for Public Policy Alternatives. Retrieved from www.cpparesearch.org/wp-content/../Country-profileon-SDGs-Nigeria-Final-Version.pdf.

Simpson R, Williams A (2011) Design of Propeller Turbines for Pico Hydro. Version 1.1c. Retrieved from www.picohydro.org.uk.

Smith N, Williams A (2003) Assessment of Pico Hydro as an Option for Off Grid Electrification in Kenya. Micro Hydro Centre Nottingham Trent University, 13571369.

Smith N, Bush SR (2010) A Light Left in the Dark: The Practice and Politics of Pico Hydro Power in the Load PDR. Energy Policy 38(1): 116-127.

Sopian K, Ab. Razak (2009) Pico Hydro: Clean Power from Small Streams. Proceedings of the $3^{\text {rd }}$ WSEAS. International Conference on Renewable Energy Sources, 414-419.

Sternberg R (2010) Hydropower's Future, the Environment, and Global Electricity Systems. Renewable and Sustainable Energy Reviews 14(2): 713-723.

Tamrakar A, Pandey SK, Dubey SC (2015) Hydro Power Opportunity in the Sewage Waste Water. American International Journal of Research in Science, Technology, Engineering \& Mathematics 10(2): 179-183.

UNIDO (2009) UNIDO and Renewable Energy: Greening the Industrial Agenda. Vienna: United Nations Industrial Development Organization, 1-32.

UNIDO (2010) UNIDO Projects for the Promotion of Small Hydro Power for Productive Use. UNIDO Evaluation Group, Independent Thematic Review, 20-39.

United Nations Department of Economic and Social Affairs - UNDESA (2014) Electricity and Education: The Benefits, Barriers, and Actions for Achieving the Electrification of Primary and Secondary Schools. Retrieved from https://sustainabledevelopment. un.org/con tent/documents/1608Electricity \%20and\%20 Education.pdf.

United Nations Framework Convention on Climate Change - UNFCCC (2015) Facilitating Technology Deployment in Distributed Renewable Electricity Generation.

von Flotow A (2012) Micro Hydro Penstock Design. Independent Study and Research Fellow Transcript Notation. Oregon State University, June 2, 2012.

Wang L (2009) A Micro Hydro Power Generation System for Sustainable Micro Grid Development in Rural Electrification in Africa. In IEE Power Energy Society Meeting, 1-8. Calgary, Canada.

WHO (2015) Health in 2015: From Millennium Development Goals (MDGs) to Sustainable Development Goals (SDGs), 3-11. Retrieved from www.who.int.

Williams J, Alhaji AF (2003) Parallel with Energy Crisis Underscore vs Vulnerability to Oil Supply Shocks Today? Oil and Gas Journal 5(Mar): 101-103.

Williams A (2007) Pico Hydro for Cost Effective Lighting. Boiling Point Magazine. 1416 May 2007.

Williamson SJ, Stark BH, Booker JD (2011) Low Head Pico Hydro Turbine Selection Using a Multi-Criteria Analysis. Linköping, Sweden: World Renewable Energy Congress, 6, 1377 - 1385.

Wohlgemuth M (2014) Assessment of Pico-Hydro Power Potential in Rural Ethiopia. BSc Thesis. Department for Hydrology and River Basin Management, Technische Universität München.

World Bank (2006) Technical and Economic Assessment of Off-Grid, Mini-Grid and Grid Electrification Technologies - Summary Report. World Bank Energy Unit, September 2006. 
World Bank (2008) The Welfare Impact of Rural Electrification: A Reassessment of the Cost and Benefit. International Evaluation Group. Retrieved from http://sitere sources.worldbank. org/EXTRURELECT/Resources/full.doc.pdf.

World Energy Council (2013) World Energy Resources - 2013 Survey. 15, 18, 19, Regency House, 1-4. Warwick Street, London. Retrieved from www.worldener gy.org.

Xuhe W, Baoshan Z, Lei T, Jie Z, Shuliang C (2014) Development of a Pump-Turbine Runner based on Multi-Objective Optimization. 27 $7^{\text {th }}$ IAHR Symposium on Hydraulic Machinery and Systems (IAHR 2014), IOP Conference Series: Earth and Environmental Science 22.

Yadav G, Chauhan AK (2014) Design and Development of Pico Micro Hydro System by Using Household Water Supply. International Journal of Research in Engineering and Technology 3(10): 114-119.

Yassi Y, Hasemloo S (2010) Improvement of the Efficiency of a New Micro Hydro Turbine at Part Loads due to Installing Guide Vane Mechanism. Energy Conversion and Management 51(10): 1970-1975.

Yuksel I (2013) Renewable Energy Status of Electricity Generation for Future Prospect. Renewable Energy 50(Feb): 1037-1043. 
